Gut, 1987, 28, 330-335

\title{
Raised serum concentrations of pancreatic enzymes in cigarette smokers
}

\author{
M A DUBICK, C N CONTEAS, H T BILLY, A P N MAJUMDAR, \\ AND M C GEOKAS
}

\begin{abstract}
From the Enzymology Research Laboratory, Department of Medicine, Veterans Administration Medical Center, Martinez, CA, and Departments of Medicine and Biological Chemistry, University of California, Davis, CA, USA
\end{abstract}

SUMMARY Circulating concentrations of digestive enzymes, certain lysosomal hydrolases and protease inhibitors were measured in 19 heavy smokers and 13 non-smokers before (basal) and at $15,30$, and 60 minutes after a single intravenous injection of secretin ( $75 \mathrm{CU})$. In smokers, basal serum amylase and immunoreactive pancreatic elastase 2 (IRE2) concentrations were about $100 \%$ and $25 \%$ higher respectively, than in the non-smokers, whereas, no differences were observed in basal immunoreactive cationic trypsinogen (IRCT) concentrations and in acid phosphatase and $\beta$ glucuronidase activities between the two groups. Furthermore, a single injection of secretin to cigarette smokers significantly increased serum amylase, IRCT and IRE2 by $155 \%, 200 \%$, and $100 \%$, respectively when compared with their corresponding basal levels. No such increment was observed in the non-smokers. In addition, there were no significant differences in serum trypsin or elastase inhibitory capacity or immunoreactive $\alpha_{1}$-protease inhibitor and $\alpha_{2}$-macroglobulin levels between smokers and non-smokers. The levels and inhibitory capacity of these protease inhibitors was also not affected by secretin injection. These data suggest that cigarette smoking enhances the responsiveness of the exocrine pancreas to a physiological stimulus such as secretin, with resultant substantial increase in the concentrations of pancreatic hydrolases in blood.

Cigarette smoking is a well recognised risk factor in the aetiology of pulmonary emphysema, ${ }^{1-3}$ coronary artery disease and aortic aneurysms, ${ }^{+7}$ and has been linked to the development of pancreatitis ${ }^{x}$ and pancreatic carcinoma." Although the mechanism(s) that relate smoking to these diseases are not well understood, enzymes with elastase-like activity have been implicated in the pathogenesis of emphysema and aortic aneurysms. ${ }^{\text {IIII }}$

Accumulating evidence suggests that nicotine affects exocrine pancreatic secretion. Several investigators ${ }^{13-15}$ have shown that cigarette smoking in man or infusion of nicotine in experimental animals inhibits both basal and secretin mediated stimulation of pancreatic fluid and bicarbonate secretion with no apparent change in protein output. In contrast, Balldin, et $\mathrm{al}^{1 \mathrm{th}}$ have observed raised serum concentrations of amylase, cationic trypsinogen and pancreatic secretory trypsin inhibitor after secretin

Address for correspondence: Dr Michacl Dubick, Department of Medicine (151F), VA Medical Center. Martine\%. ('A 94553. USA

Received for publication 3 July 1986. injection in cigarette smokers. We have recently shown that exposure of isolated rat pancreatic acini to nicotine greatly stimulates the secretion of preformed exportable hydrolases and newly synthesised proteins..$^{17 \mathrm{Ix}}$ This observation indicates that nicotine exerts a direct effect on the exocrine pancreatic cell.

In addition to nicotine, tobacco smoke also contains other cytotoxic agents which may affect exocrine pancreatic function. For example, recent data from this laboratory demonstrate that acetaldehyde, the primary metabolite of ethanol and a constituent of tobacco smoke ${ }^{19}$ inhibits cholecystokinin induced amylase release from isolated pancreatic acini and the binding of cholecystokinin to acinar membranes. ${ }^{20}$

The present study was undertaken to further investigate alterations in the responsiveness of the exocrine pancreas to secretin stimulation and its effect on the protease antiprotease balance in heavy cigarette smokers. The circulating levels of digestive enzymes, certain lysosomal hydrolases and protease inhibitors were measured in serum from non- 
smokers and heavy smokers of different ages before and after a single iv injection of secretin. Furthermore, efforts were also made to relate these findings to the history of alcohol consumption in the subjects.

\section{Methods}

SUBJECTS

Nineteen smokers (16 men, three women) were recruited from the patients and staff of the VA Medical Center (Martinez, CA). Except for one subject, all had smoked for a minimum of eight years with a smoking history of $65 \cdot 7 \pm 8 \cdot 1$ pack years (mean \pm SEM). The majority smoked at least two packs of cigarettes/day. The subjects ranged in age from 30-68 years $(52 \cdot 2 \pm 2 \cdot 5)$ and 13 of them consumed significant amounts of alcohol regularly. Although coffee consumption was not controlled for this study, Andriulli et $a^{21}$ found that coffee intake did not affect serum trypsin concentrations after secretin injection. Nine young, healthy, volunteer students (four men, five women), ranging in age from 25-35 years, served as controls with no history of smoking or alcohol abuse. In addition, four male non-smokers, ranging in age from 53-76 years served as controls to the more aged smokers. Subjects were fasted overnight before testing and the smokers were allowed to smoke up to the test period.

BLOOD SAMPLES AND SECRETIN INJECTION

Venous blood was obtained before and 15,30 , and 60 minutes after a single rapid injection (iv over $1 \mathrm{~min}$ ) of $75 \mathrm{CU}$ of secretin (KabiVitrum CB Laboratories, Stockholm, Sweden). Blood was allowed to coagulate on ice for at least two hours and serum was isolated by centrifugation $(2000 \mathrm{~g}, 15 \mathrm{~min})$. Serum was stored at $-80^{\circ} \mathrm{C}$ until assayed.

ENZYMES AND SUBSTRATES

Bovine trypsin (EC 3.4.4.4) and porcine pancreatic elastase (EC 3.4.21.11) were obtained from Worthington Biochemical Corp, Freehold, NJ. Porcine pancreatic amylase was a product of Calbiochem-Behring (LaJolla, CA). Tosyl-argininemethyl ester (TAME) and succinyl-tri-alanine-pnitroanilde (SLAPNA) were from Sigma Chemical Co (St Louis, MO). Agarose was purchased from Biorad Laboratories (Richmond, CA). All reagents used for biochemical measurements were of analytical grade or the purest commercially available.

ENZYME ASSAYS

Amylase

Amylase concentrations in serum were determined by the method of Jung ${ }^{22}$ using procion yellow coupled to starch as substrate.
Hydrolases

$\beta$-glucuronidase and acid phosphatase activity was determined colorimetrically according to Sigma Technical Bulletins 325 and 104, respectively. $\beta$ glucuronidase activity was expressed a microgram phenolphthalein liberated $/ \mathrm{h} / \mathrm{ml}$. Acid phosphatase activity was expressed as umoles p-nitrophenol liberated $/ \mathrm{h} / \mathrm{ml}$.

\section{Gamma-glutamyl transpeptidase}

Gamma-glutamyl transpeptidase activity was assayed by the colorimetric procedure outlined in Sigma Technical Bulletin 545 .

\section{RADIOIMMUNOASSAYS}

Serum immunoreactive cationic trypsin(ogen) (IRCT) and immunoreactive elastase 2 (IRE2) concentrations were determined by radioimmunoassay as previously described ${ }^{23}$ except that $0 \cdot 12 \%$ normal rabbit immunoglobulin was removed from the assay buffer. After a four day incubation at $4^{\circ} \mathrm{C}$, the antigen-antibody complex was precipitated with goat-antirabbit immunoglobulin bound to agarose. A dilution of 1:1000000 of specific antiserum to both enzymes was used. Three appropriate dilutions were analysed in duplicate and results were expressed as $\mathrm{ng} / \mathrm{ml}$ of cationic trypsin(ogen) or elastase 2 by comparison with purified human cationic trypsin or elastase 2 as standards.

OTHER ASSAYS

The concentrations of immunoreactive $\alpha_{1}$-protease inhibitor $\left(\alpha_{1}-\mathrm{PI}\right)$ and $\alpha_{2}$-macroglobulin $\left(\alpha_{2}-\mathrm{M}\right)$ in serum were determined by the rocket immunoelectrophoresis procedure of Laurell and McKay.24

Trypsin inhibitory capacity was determined by incubation of a known amount of purified bovine trypsin with serum and measuring the inhibition of trypsin hydrolysis of TAME. "s Inhibitory capacity was assessed from the difference in slope in the absence (water blank) and presence of serum. Elastase inhibitory capacity was measured similarly by inhibition of the hydrolysis of SLAPNA after incubation of purified pancreatic elastase with serum..$^{26}$

Serum albumin concentrations were determined by the bromocresol green dye-binding assay (Sigma Chemical Co). Methemalbumin was assayed by the method of Walberg et $\mathrm{l}^{27}$ and results were expressed as milligrams haematin $/ 100 \mathrm{ml}$.

STATISTICAL ANALYSIS

Results were analysed by Student's $t$ test for comparison of the means between the smokers and non-smokers and basal and stimulated values within groups. 


\section{Results}

It was observed that both the basal and secretin stimulated levels of amylase and immunoreactive cationic trypsin(ogen) and elastase 2 were similar in both the young and aged non-smokers. Consequently, all non-smoking subjects were combined into a single group.

In smokers basal serum amylase and immunoreactive elastase 2 concentrations were found to be $100 \%$ and $24 \%$ higher, respectively, than in the nonsmokers (Figure). Serum IRCT concentrations between the two groups were, however, the same (Figure). These observations remained unchanged when the smokers were subdivided according to age $(>50$ years old) or their drinking habits (those who consumed alcohol regularly).

A single injection of secretin increased serum amylase concentrations an additional $2 \cdot 6$-fold in all smokers, and 3.2-fold in those who smoked and drank alcohol (smoking+drinking group) (Figure). Serum enzyme concentrations in the smokers group were higher at all time periods in comparison with controls. Therefore, only the maximum stimulated levels (at $15 \mathrm{~min}$ ) are reported. Serum amylase concentrations in the non-smoking controls were unaffected by the hormone (Figure). In addition, serum IRCT and IRE2 levels were 3.4 and $2 \cdot 1$-fold higher, respectively, after secretin injection, than their corresponding basal levels (Figure). Again the greatest stimulation in circulating levels of pancreatic proteases was observed in the 'smoking+drinking' group. In general data from individual smokers showed that the secretin stimulated increase of amylase was accompanied by raised serum cationic trypsin(ogen) and elastase 2 . None of these changes were observed in the non-smoker control subjects (Figure). We wish to emphasise that whereas trypsinogen and elastase 2 are pancreas specific, the origin of the increased concentrations of amylase cannot be ascertained because assay for amylase isoenzymes was not performed.

As shown in Table 1 , the basal levels of immunoreactive $\alpha_{1}$-protease inhibitor $\left(\alpha_{1}-\mathrm{PI}\right)$ and $\alpha_{2}$ -
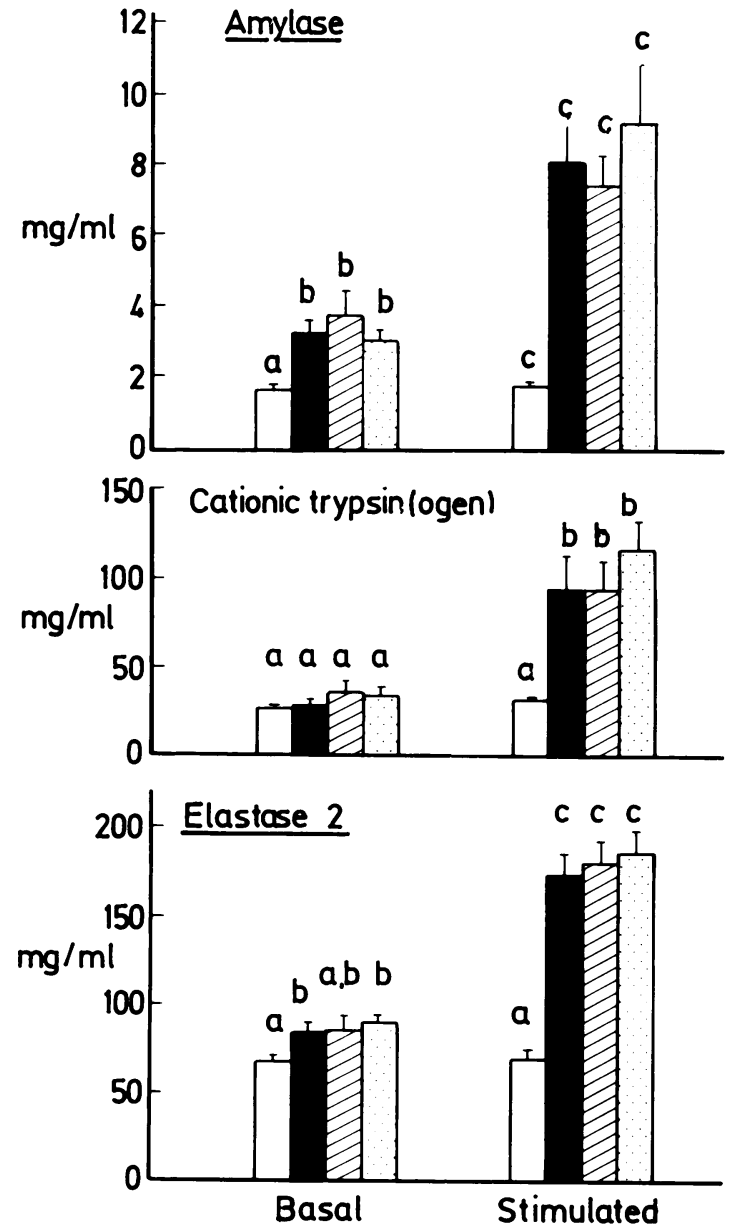

Figure Concentrations of amylase, cationic trypsin(ogen) and elastase 2 in serum. Data expressed as mean $\pm S E$ of 10-19 samples. Open bar, non-smokers; closed bar, all smokers; hatched bar, smokers over 50 years old; stippled bar, smokers and drinkers. Means with different letters are significantly different $(p<0 \cdot 05)$.

macroglobulin $\left(\alpha_{2}-\mathrm{M}\right)$ in any of the categories of smokers were the same or slightly higher in comparison with the controls. Similar results were observed

Table 1 Serum protease-inhibitorlevels and activity*

\begin{tabular}{|c|c|c|c|c|}
\hline & $\begin{array}{l}\text { Non-smokers } \\
n=1.3\end{array}$ & $\begin{array}{l}A \| l \\
n=19\end{array}$ & $\begin{array}{l}\text { Simokers } \\
\text { Simokers over } 50 \text { years old } \\
n=10\end{array}$ & $\begin{array}{l}\text { Simoke }+ \text { drink } \\
n=1.3\end{array}$ \\
\hline$\alpha_{1}-\mathrm{PI}+(\mathrm{mg} / 100 \mathrm{ml})$ & $317 \pm 14$ & $328 \pm 19$ & $322 \pm 27$ & $317 \pm 23$ \\
\hline$\alpha_{2}-\mathrm{M}_{\ddagger} \neq(\mathrm{mg} / 100 \mathrm{ml})$ & $194 \pm 1.3$ & $229 \pm 15$ & $200) \pm 18$ & $225 \pm 17$ \\
\hline TIC $\$(\%$ inhib/10 $\mu l)$ & $39 \cdot 2 \pm 2 \cdot 1$ & $37 \cdot 6 \pm 2.5$ & $4(1) .7 \pm 3.2$ & $34.9 \pm 3.6$ \\
\hline ELC $\|(\%$ inhib/20 $\mu l)$ & $7.3 .1 \pm 2.4$ & $76 \cdot 1 \pm 3 \cdot 3$ & $8(1) .5 \pm 3.0$ & $81.9 \pm 2.2$ \\
\hline
\end{tabular}

${ }^{*}$ Data expressed as mean \pm SE; $\alpha_{1}$-Protease inhibitor: $\alpha_{2}$-Macroglobulin: $\$$ Trypsin-inhibitory capacity: ||Elastase-inhibitory capacity. 
with respect to assessment of elastase-inhibitory capacity of $\alpha_{1}$-PI (Table 1). In most cases, however, trypsin inhibitory capacity of $\alpha_{1}$-PI was slightly higher in the non-smokers, though the differences were not statistically significant. In addition none of these parameters were significantly affected by secretin in any group. Thus, these data translate into a two to three fold increase in the protease-toprotease inhibitor ratio in serum from heavy smokers after secretin administration (Figure, Table 1).

Furthermore, no significant differences were noted in circulating concentrations of lysosomal hydrolases between the smokers and non-smokers during the course of the study (Table 2). Acid phosphatase and $\beta$-glucuronidase activity was within normal limits in all but two smokers. Again these two individuals were heavy drinkers as well. $\gamma$-glutamyl transpeptidase activity was, however, higher in all groups of smokers than in controls (Table 2). Raised $\gamma$ glutamyl transpeptidase activity was particularly pronounced in individuals who were also heavy drinkers.

Smokers also had lower serum albumin concentrations compared with non-smokers (Table 2), and no methemalbumin was detected in serum from smokers either before or after secretin administration.

\section{Discussion}

The exocrine pancreas is one of the most metabolically active organs in the body, as evidenced by its high rate of protein synthesis. Its major function is to secrete into the gut, on demand, large quantities of bicarbonate, water and digestive enzymes. ${ }^{2 x}$ Under normal conditions, pancreatic enzymes enter the duodenum via the pancreatic duct, with a small fraction being directly secreted into the blood. ${ }^{23}{ }^{24} \mathrm{In}$ serum from normal healthy adults, fasting levels of immunoreactive trypsinogen and elastase 2 averaged $26 \mathrm{ng} / \mathrm{ml}^{311}$ and $71 \mathrm{ng} / \mathrm{ml},{ }^{31}$ respectively, with no significant variation between adults of various ages. ${ }^{21}{ }^{130} 31$ This observation is consistent with data obtained from the non-smokers in this study. In contrast, it is known that pancreatic inflammation results in a profound rise in circulating concentrations of pancreatic hydrolases. ${ }^{32}$
Although the smokers used in the present study were apparently healthy, their basal circulating concentrations of amylase and immunoreactive elastase 2 were found to be significantly higher than in the non-smoking controls. Furthermore, a single injection of secretin produced a profound rise in serum amylase, immunoreactive cationic trypsin(ogen) and elastase 2 . This effect was not seen in the non-smokers. Balldin et $\mathrm{al}^{16}$ and Andriulli et al ${ }^{21}$ have also observed a rise in serum immunoreactive trypsin concentrations in smokers after secretin injection. Whether these results are because of increased synthesis and/or enhanced secretion of enzymes, is at present unknown. We have recently observed, however, that in rats, administration of acetaldehyde, the primary metabolite of ethanol and a constituent of tobacco smoke, ${ }^{19}$ significantly reduced the amylase and trypsinogen content of the pancreas and increased serum amylase concentrations ${ }^{33}$ Further, it was observed that in dispersed pancreatic acini from acetaldehyde treated rats, basal secretion of preformed exportable hydrolases, amylase, trypsinogen and chymotrypsinogen was increased $40-50 \%$ over control levels and nicotineinduced enzyme release was enhanced. ${ }^{33}$ These data suggest that acetaldehyde treatment enhances pancreatic enzyme secretion. Since similar results have been observed after nicotine infusion in rats (Majumdar, Dubick, V'esenka and Geokas - unpublished observations), it appears that heavy cigarette smoking may result in an accelerated secretion of pancreatic enzymes.

Because pancreatic secretion into the duodenum was, however, not measured in this study, the precise mechanism(s) for the increased serum enzyme concentrations observed remain unknown. Previous studies have shown that nicotine infusion ${ }^{15}$ it or cigarette smoking ${ }^{1325}$ alter interdigestive pancreatic exocrine secretion into the duodenum. As bile secretion into the duodenum is also affected by cigarette smoking, ${ }^{35}$ it is possible that smoking may induce an 'exit block' at the level of the sphincter of Oddi. At present we are unaware of any studies on the direct effects of nicotine or cigarette smoking on sphincter of Oddi motility.

Table 2 Serumalbumin lysosomal hydrolases and GGTP* activity ${ }^{\dagger}$

\begin{tabular}{|c|c|c|c|c|}
\hline & $\begin{array}{l}\text { Non-smokers } \\
n=1.3\end{array}$ & $\begin{array}{l}A l l \\
n=I 9\end{array}$ & $\begin{array}{l}\text { Sinokers } \\
\text { Simokersover } 50 \text { yearsold } \\
n=10\end{array}$ & $\begin{array}{l}\text { Sinoke }+ \text { drink } \\
n=1.3\end{array}$ \\
\hline Acid phosphatase ( $\mu$ mole $p$-nitrophenol $/ \mathrm{h} / \mathrm{ml}$ ) & $0.27 \pm 0 \cdot() 2$ & $(0.34 \pm 0.0 .3$ & $0.37 \pm 0.05$ & $(1) .37 \pm 0 .(1) 4$ \\
\hline$\beta$ Glucuronidase ( $\mu \mathrm{g}$ phenophthalein $/ \mathrm{h} / \mathrm{ml}$ ) & $21 \cdot 5 \pm 2 \cdot 8$ & $25 \cdot 1 \pm 3 \cdot 3$ & $19.2 \pm 2.2$ & $21 \cdot 6 \pm 2 \cdot 8$ \\
\hline GGTP (units/ml) & $14 \cdot 1 \pm 1 \cdot 8$ & $32 \cdot 9 \pm 7 \cdot 8 \div$ & $42 \cdot 2 \pm 12 \cdot 5$ & $4(0 \cdot 0 \pm 10 \cdot 5$ \\
\hline
\end{tabular}

${ }^{*}$ Gamma glutamyl transpeptidase: + Data expressed as mean $\mu \mathrm{SE}:+\mathrm{p}<() \cdot(0.5$. 
It also appears that the effect of secretin on pancreatic enzyme secretion is multifactorial. After secretin infusion in six patients, Gullo, et $a l^{\text {is }}$ concluded that secretin induced pancreatic enzyme secretion through a direct action on the acinar cells, while Carr-Locke et al observed that secretin infusion selectively relaxed the pancreatic duct sphincter without any effect on the common bile duct or bile duct sphincters. DiMagno $e t a l^{3 *}$ also observed that secretin dilated the pancreatic duct and decreased the flow of pancreatic juice into the duodenum. A differential effect of secretin on duct and sphincter pressures could also result in an 'exit block' and may explain, in part, the observed effects of secretin on serum amylase and lipase in patients with biliary and pancreatic disease. ${ }^{. "}$ Further studies in this area are clearly indicated.

In addition, the present study showed that the secretin stimulated serum levels of pancreatic hydrolases tended to be only slightly higher in the subjects who smoked and imbibed alcohol regularly, as compared with the cigarette smokers group as a whole. Although numerous studies have shown that ethanol affects exocrine pancreatic function both in vitro and in vivo, ${ }^{\text {th- }}$ the present data do not support an additive effect of cigarette smoking and ethanol consumption on exocrine pancreatic secretion.

Our study also shows that trypsin and elastase inhibitory capacity and circulating levels of $\alpha_{1}-\mathrm{PI}$ and $\alpha_{2}-\mathrm{M}$ were not significantly different between smokers and non-smokers. Carp and Janoff' found that fresh cigarette smoke could suppress elastaseinhibitory capacity in vitro and Beatty et $\mathrm{al}^{+3}$ reported the presence of oxidised $\alpha_{1}$-PI in serum from cigarette smokers. Other investigators, ${ }^{+1+5}$ however, did not observe decreased protease inhibitory capacity in cigarette smokers. Although protease inhibitory capacity was not significantly compromised in the smokers of this study, the data show an increase in the protease to inhibitor ratio in serum from cigarette smokers. This condition has been hypothesised as a major factor in the pathogenesis of pulmonary emphysema and aortic ane!nrysms. ${ }^{31112}$

Thus, the results of the present study as well as those of others ${ }^{1021}$ indicate that secretin induces increased circulating levels of pancreatic proteases in heavy cigarette smokers, without affecting enzyme levels in non-smokers. Therefore, it is tempting to speculate that an enhanced responsiveness of the pancreas to physiological stimuli - for example, in response to food intake resulting in hormonal secretion, may result in episodic increases in circulating protease levels in chronic cigarette smokers. With the increased protease/inhibitor ratio observed in serum in our present study, and our recent detection of immunoreactive pancreatic cationic trypsin(ogen) and elastase 2 in human abdominal aortic aneurysms," these studies suggest that circulating pancreatic proteolytic enzymes could be operative, at least in part, in the initiation of pulmonary emphysema and aortic aneurysms, diseases often associated with heavy cigarette smoking. Work is now in progress in order to investigate this hypothesis.

$\mathrm{H} T$ Billy is the recipient of a student fellowship from the American Heart Association, California Affiliate.

This work was supported by the Medical Research Service of the Veterans' Administration and by a Grant-in-Aid from the American Heart Association, California Affiliate and with funds contributed by the American Heart Association, Santa Clara County Chapter.

\section{References}

1 Carp H, Janoff A. Possible mechanisms of emphysema in smokers. In vitro suppression of serum elastaseinhibitory capacity by fresh cigarette smoke and its prevention by antioxidants. Am Rev Respir Dis 1978; 118: $617-21$

2 Hoidel JR, Niewochrer DE. Cigarette smoke inhalation potentiates elastase-induced emphysema in hamsters. Am Rev Respir Dis 1983; 127: 478-81.

3 Janoff A, Carp H, Laurent P, Raju L. The role of oxidative processes in emphysema. Am Rev Respir Dis 1983; 127: S31-S38.

4 Kaufman DW, Helmrich SP, Rosenberg L, Miettinen OS, Shapiro S. Nicotine and carbon monoxide content of cigarette smoke and the risk of myocardial infarction in young men. $N$ Engl J Med $1983 ;$ 308: 409-13.

5 Auerbach O, Garfinkel L. Atherosclerosis and aneurysm of aorta in relation to smoking habits and age. Chest 1980; 78: 805-9.

6 Hill P, Haley NJ, Wynder EL. Cigarette smoking: Carboxyhemoglobin, plasma nicotine, cotine and thiocyanate vs self-reported smoking data and cardiovascular disease. J Chronic Dis 1983; 36: 439-49.

7 Hartz AJ, Anderson AJ, Brooks HL, Manley JC, Parent GT, Barboria JJ. The association of smoking with cardiomyopathy. $N$ Engl J Med 1984; 311: 1201-6.

8 Yen S, Hsieh C-C, MacMahon B. Consumption of alcohol and tobacco and other risk factors for pancreatitis. Am J Epidemiol 1982; 116: 407-14.

9 Schmidt W, Popham RE. The role of drinking and smoking in mortality from cancer and other causes in male alcoholics. Cancer 1981; 47: 1031-41.

1) Kuhn C. Senior RM. The role of elastases in the development of emphysema. Lung 1978; 155: 185-97.

11 Cannon DJ, Read RC. Blood elastolytic activity in patients with aortic aneurysm. Ann Thorac Surg 1982; 34: $10-15$

12 Busuttil RW, Rinderbriecht H, Flesher A, Carmack C. Elastase activity: The role of elastase in aortic aneurysm formation. J Surg Res 1982; 32: 214-7. 
13 Bynum TE, Solomon TE, Johnson LR, Jacohson ED. Inhibition of pancreatic secretion in man by cigarette smoking. Gut 1972; 13: 362-5.

14 Murthy SNS, Dinoso VP, Clearfield HR, Chey WY. Simultaneous measurement of basal pancreatic, gastric acid secretion, plasma gastrin and secretin during smoking. Gastroenterology 1977; 73: 758-61.

15 Konturek SJ, Solomon TE, McCreight WG, Johnson LR, Jacobson EG. Effects of nicotine on gastrointestinal secretions. Gastroenterology 1971; 60: 1098-105.

16 Balldin G, Borgstrom A, Eddeland A, Genell S, Hagberg L, Ohlsson K. Elevated serum levels of pancreatic secretory proteins in cigarette smokers after secretin stimulation. J (lin Invest 1980; 66: 15962.

17 Majumdar APN, Davis GA, Dubick MA, Geokas MC. Nicotine stimulation of protein secretion from isolated rat pancreatic acini. Am $J$ Physiol 1985; 248: G158-G163.

18 Geokas MC, Dubick MA, Davis GA, Majumdar APN. Effect of nicotine on the synthesis and secretion of proteins in isolated rat pancreatic acini. Physiologist 1984; $27: 272$.

19 Newsome JR, Normal V, Keith CW. Vapour phase analysis of cigarette smoke. Tobacco Sci 1965; 9: $102-10$.

20) Sankaran H, Lewin MB, Wong A, DeVeney CW, Leimgruber MF. Geokas MC. Irreversible inhibition by acetaldehyde of cholecystokinin-induced amylasesecretion from isolated rat pancreatic acini. Biochem Pharmacol 1985; 34: 2859-63.

21 Andriulli A, Masoero G, Amato A, et al. Serum immunoreactive cationic trypsinogen response to secretin in normal subjects. Am J Gastroenterol 1983; 78: $579-83$.

22 Jung DH. Preparation and application of procion yellow starch for amylase assay. Clin Chim Acta 1980; 100: $7-11$.

23 Largman C, Brodrick JW, Geokas MC. Radioimmunoassay determination of circulating pancreatic endopeptidases. Methods Enzymol 1981; 74: 2729 ().

24 Laurell CB, McKay EJ. Electroimmunoassay. Methods Enzymol 1981; 73: 339-69.

25 Mayer M, Fedgar S, Joffe M, Shafrir E. Urine protease and antiprotease activity in experimental aminonucleoside nephrotoxicity. Nephron 1981; 29: 223-8.

26 Travis J, Johnson D. Human $\alpha_{1}$-proteinase inhibitor. Methods Enzymol 1981; 80: 754-65.

27 Walberg CB, Geokas MC, Rinderknecht H. Determination of serum methemalbumin. Clin Chim Acta 1973; 48: 229-32.

28 Geokas MC. Ethanol and the pancreas. Med Clin N Am 1984: 68: $57-75$.

29 Geokas MC, Largman C. Brodrick JW, Fassett M. Molecular forms of immunoreactive pancreatic elastase in canine pancreatic and peripheral blood. Am J Physiol 1980; 238: G238-G246.

30) Geokas MC, Largman C, Brodrick JW, Johnson JH. Determination of human pancreatic cationic trypsino- gen in serum by radioimmunoassay. Am J Physiol 1979; 236: E77-E83.

31 Geokas MC, Brodrick JW, Johnson JH, Largman C. Pancreatic elastase in human serum. Determination by radioimmunoassay. J Biol Chem 1977; 252: 61-7.

32 Balart LA, Ferrante WA. Pathophysiology of acute and chronic pancreatitis. Arch Intern Med 1982; 142: 113-7.

33 Majumdar APN, Vesenka GD, Dubick MA, Yu GSM, DeMorrow JM. Geokas MC. Morphological and biochemical changes of the pancreas in rats treated with acetaldehyde. Am J Physiol 1986; 250: G598-G606.

34 Keane FB, Dozois RR, Go VLW, DiMagno EP. Nicotine induces simultaneous canine interdigestive pancreatic exocrine secretion and duodenal motility. [Abstract]. Clin Res 1979; 27: 633A.

35 Bell JS, Go VLW, DiMagno EP. Cigarette smoking normalizes the interdigestive pancreatic exocrine and biliary secretion of heavy smokers. Gastroenterology 1981; 80: 1108 .

36 Gullo L, Priori P. Costa PL, Mattioli G, Labo G. Action of secretin on pancreatic enzyme secretion in man. Studies on pure pancreatic juice. Gut 1984; 25: 867-73.

37 Carr-Locke DL, Gregg JA, Chey WY. Effects of exogenous secretin on pancreatic and biliary ductal and sphincteric pressures in man demonstrated by endoscopic manometry and correlation with plasma secretin levels. Dig Dis Sci 1985; 30: 909-17.

38 DiMagno EP, Hendricks JC, Dozois RR, Go VLW. Effect of secretin on pancreatic duct pressure, resistance to pancreatic flow and duodenal motor activity in the dog. Dig Dis Sci 1981; 26: 1-6.

39 Burton P, Hammond EM, Harper AA, Howat HT, Scott JE, Varley H. Serum amylase and serum lipase levels in man after administration of secretin and pancreozymin. Gut 1960; 1: 125-39.

40) Uhlemann ER, Robberecht P, Gardner JD. Effects of alcohol on the action of VIP and secretin on acinar cells from guinea pig pancreas. Gastroenterology 1979; 76: 917-25.

41 Fried GM, Ogden WD, Zhu X-G, Greeley, Jr GH, Thompson JC. Effect of alcohol on the release of cholecystokinin and pancreatic enzyme secretion. Am J Surg 1984; 147: 53-7.

42 Rinderknecht H, Stace NH, Renner IG. Effects of chronic alcohol abuse on exocrine pancreatic secretion in man. Dig Dis Sci 1985; 30: 65-71.

43 Beatty K, Robertie P, Senior RM, Travis J. Determination of oxidized alpha-1-proteinase inhibitor in serum. J Lab Clin Med 1982; 100: 186-92.

44 Stone PJ, Calore JD, McGowan DE, Bernardo J, Snider GL, Franzblau C. Functional $\alpha_{1}$-protease inhibitor in the lower respiratory tract of cigarette smokers is not decreased. Science 1983; 221: 1187-9.

45 Abboud RT, Fera T, Richter A, Tabona MZ, Johal S. Acute effect of smoking on the functional activity of $\alpha_{1}$ protease inhibitor in bronchoalveolar lavage fluid. $\mathrm{Am}$ Rev Respir Dis 1985; 131: 79-85.

46 Dubick MA, Hunter GC, Perez-Lizano E, Majumdar APN, Geokas MC. Involvement of pancreatic proteases in human abdominal aortic aneurysms. [Abstract]. Clin Res 1986; 34: 28A. 